\section{MicroRNAs regulate tolerance mechanisms in sugarcane (Saccharum spp.) under aluminum stress}

\section{Jóice de Oliveira Leite Silva ${ }^{1}$, Renan Gonçalves da Silva², Lucas de Faria Nogueira ${ }^{1}$ and Sonia Marli Zingaretti ${ }^{1^{*}}$}

\begin{abstract}
The agricultural yield of sugarcane (Saccharum spp.) is influenced by various abiotic stresses, including aluminum toxicity $\left(A{ }^{\beta+}\right)$. MicroRNAs (miRNAs) play a role in plant tolerance to such stresses by modulating the expression of several important target genes involved in plant growth. This study investigated the possible tolerance mechanisms of two sugarcane genotypes (CTC-2 and RB855453) under $A{ }^{\beta+}$ stress through miRNA expression profiles and in silico analysis of target genes. The expression data obtained using RT-qPCR and coexpression network analysis identified two possible regulatory mechanisms in the tolerant genotype (CTC-2) under $A^{3+}$ stress. miR395 was involved in $A^{\beta^{3+}}$ detoxification, whereas miR160, miR6225-5p, and miR167 participated in the process of lateral root formation, conferring tolerance to the genotype. These findings might be useful for biotechnological strategies that aim for miRNA silencing or gene overexpression and provide subsidies for future genetic improvement programs aimed at the development of abiotic stress-tolerant sugarcane genotypes.
\end{abstract}

Keywords: Aluminum toxicity, co-expression network, RT-qPCR, Saccharum, small RNAs.

\section{INTRODUCTION}

Sugarcane (Saccharum spp.) is one of the most important crops for the global economy, and Brazil is the largest producer of sugarcane worldwide (annual production of 746 million tons) (FAOSTAT 2018). Sugarcane is used primarily in sugar and bioenergy production and in animal feeds (Torquato and Ramos 2013). Expansion of sugarcane cultivation to different regions of the country increased its production and supply; however, such expansion is associated with exposure to various adverse factors such as drought, salinity, and ion toxicity, which negatively affect its yield (Devarumath et al. 2019).

Aluminum toxicity $\left(\mathrm{Al}^{3+}\right)$ is one of the main factors limiting agricultural productivity in acidic soils (Liu et al. 2014). At a soil pH close to or below 5, Al-containing molecules are solubilized and released into the environment as toxic $\mathrm{Al}^{3+}$ ions (Wu et al. 2018), which can reduce root system growth, thus preventing water and nutrient absorption (Nogueirol et al. 2015) and altering plant oxidative and molecular metabolism (Inostroza-Blancheteau et al. 2011). Plants respond to stress conditions by different mechanisms, and among them, plants can regulate the expression of specific genes or through microRNA (miRNA)-mediated post-transcriptional regulation (Çelik and Akdas 2019).
Crop Breeding and Applied Biotechnology 21(1): e34442115, 2021 Brazilian Society of Plant Breeding. Printed in Brazil http://dx.doi.org/10.1590/198470332021v21n1a5
${ }^{*}$ Corresponding author:
E-mail: szingaretti@unaerp.br
(i) ORCID: 000-0001-67554153

Received: 05 September 2020 Accepted: 27 November 2020 Published: 31 January 2021

${ }^{1}$ Universidade de Ribeirão Preto, Unidade Biotecnologia, Av. Costábile Romano, Ribeirânia, 14.096-900, Ribeirão Preto, SP, Brazil

2 Universidade Estadual Paulista (UNESP), Escola de Ciências Agrícola e Veterinária Jaboticabal, Via de acesso Professor Paulo Donato Castelane Castellane, Vila Industrial, 14.884-900, Jaboticabal, SP, Brazil 
miRNAs are small, non-coding RNAs that consist of 20 to 25 nucleotides and regulate the accumulation of target genes involved in different metabolic processes, such as vegetative growth and biotic and abiotic stress responses (Xie et al. 2015). In corn roots under Al stress, 278 miRNAs were identified, of which 246 were conserved and 32 were new (Kong et al. 2014). In barley roots, several miRNAs belonging to the miR156, miR166, miR159, and miR160 families have been identified (Wu et al. 2018). Zeng et al. (2012) identified 30 miRNAs in Al-treated soybean, and interestingly, in this study, miR396 and miR390 were upregulated. However, in sugarcane cultivars that are tolerant to Al stress, other miRNAs, such as miR159 and miR164 were downregulated (Silva et al. 2019). Additionally, Silva et al. (2019) observed more than 390 miRNAs differentially expressed in two sugarcane cultivars with contrasting tolerance to aluminum stress.

Physiological responses of plants can vary depending on crop, genotype, and cultivar, as they result from the expression of different sets of genes and are regulated by varying underlying mechanisms. Recently, owing to the significant amount of data available, co-expression and gene regulatory networks have been used to identify and predict the functionality of individual genes within a biological system (Walley et al. 2016). These co-expression networks have been particularly important in identifying biological mechanisms by clarifying the interactions between genes (Rao and Dixon 2019). Assessing plant responses to abiotic stresses using co-expression networks provides a better understanding of the underlying regulatory mechanisms, thus facilitating the establishment of strategies to develop stress-tolerant plants (Pandey et al. 2020).

Therefore, considering the importance of miRNA-mediated genetic regulation and the possible genetic interactions identified by expression and co-expression analyses, a miRNA-mediated genetic interaction and regulation model was proposed to explain the tolerance mechanisms of sugarcane under $\mathrm{Al}^{3+}$ toxicity.

\section{MATERIAL AND METHODS}

\section{Plant material}

Sixty days old pre-germinated seedlings of two sugarcane genotypes (Saccharum spp.) with contrasting $\mathrm{Al}^{3+}$ tolerance (i.e., tolerant CTC-2 and sensitive RB855453) were used in this study. The plants were acclimatized in a hydroponic system in a greenhouse, under controlled temperature $\left(25.8 \pm 2{ }^{\circ} \mathrm{C}\right)$ and humidity $(75 \% \pm 10 \%)$ conditions and an $8 / 16$ $\mathrm{h}$ dark/light photoperiod for $20 \mathrm{~d}$. The plants were then maintained in a nutrient solution containing 0 or $221 \mu \mathrm{moL} \mathrm{L}^{-1}$ of aluminum chloride hexahydrate $\left(\mathrm{AlCl}_{3}-6 \mathrm{H}_{2} \mathrm{O} ; \mathrm{pH} 4.5\right)$ for $7 \mathrm{~d}$. The roots were then collected and stored at $-80{ }^{\circ} \mathrm{C}$ for subsequent RNA extraction.

\section{miRNA extraction and cDNA synthesis}

Total RNA was isolated from the root tissue samples using the Spectrum ${ }^{\text {TM }}$ Plant Total RNA kit (Sigma-Aldrich, USA) and quantified using a NanoDrop ${ }^{\text {TM }} 2000$ Spectrophotometer (Thermo Scientific, USA). The quality of the extracted RNA was assessed on denaturing agarose gel (1\%), and cDNA was then synthesized using the RevertAid First Strand cDNA Synthesis kit (Thermo Scientific, USA) and RT primers (long stem-loop extension primers) (Table 1), according to the instructions of the manufacturers.

Table 1. The primer sequences used in the cDNA synthesis and RT-qPCR validation

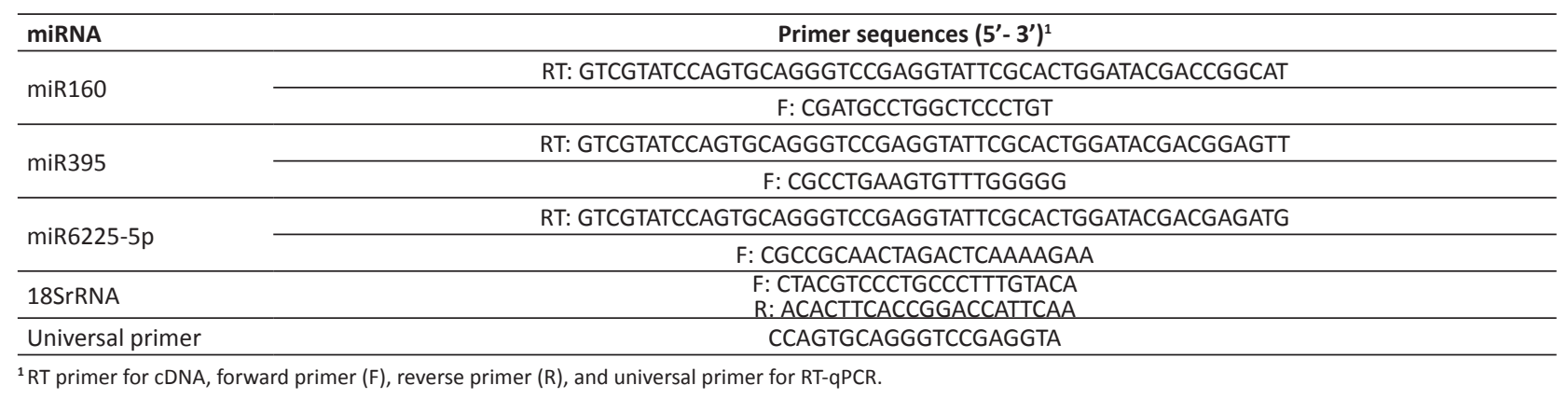




\section{Evaluation of miRNA expression using RT-qPCR}

The expression of miR160, miR395, and miR6225-5p was evaluated using the RT-qPCR stem-loop method described by Varkonyi-Gasic and Hellens (2011), using the SYBR Green Jump Start Taq Ready Mix (Sigma Aldrich, USA). Specific nucleotide sequences (forward primers) were used for each selected miRNA, and a universal primer was used for all miRNAs (Table 1). The $18 S$ rRNA gene was used to normalize the data. The amplification conditions were: $94^{\circ} \mathrm{C}$ for 2 min, followed by 40 cycles of $94{ }^{\circ} \mathrm{C}$ for $15 \mathrm{~s}, 60^{\circ} \mathrm{C}$ for $1 \mathrm{~min}$, and $72{ }^{\circ} \mathrm{C}$ for $30 \mathrm{~s}$; and a final cycle of $95{ }^{\circ} \mathrm{C}$ for $1 \mathrm{~min}, 55^{\circ} \mathrm{C}$ for $30 \mathrm{~s}$, and $95^{\circ} \mathrm{C}$ for $30 \mathrm{~s}$ to obtain the dissociation curve. miRNA expression levels were analyzed using MxPro QPCR software version 4.10 (Stratagene, USA). Three biological replicates were tested to ensure reproducibility. Relative expression levels were determined as the ratio of miRNA expression levels in the treated and control plants, with the latter assigned a value of 1 .

\section{In silico analysis}

To identify the mechanisms involved in miRNA-mediated tolerance, it was necessary to first identify the miRNAmodulated genes. The mature miRNA sequences were obtained from the miRBASE database (http://www.mirbase.org/), and miRNA-modulated genes were predicted using psRNATarget software (http://plantgrn.noble.org/psRNATarget/) (Dai et al. 2018) and WMD3-Web microRNA Designer 3.2 (http://wmd3.weigelworld.org/) (Schwab et al. 2006). Target annotation (biological process, molecular function, and subcellular localization) was performed using GeneOntology (http:// geneontology.org/) and Uniprot (https://www.uniprot.org/) online tools. Co-expression networks were constructed using the GeneMANIA prediction server software, with default analysis parameters (https://genemania.org/) (Ward-Farley et al. 2010). Arabidopsis thaliana was used as the reference genome for all analyses. In addition to miR160, miR395, and miR6225-5p, miR159, miR167, and miR168 were included in the co-expression analysis because of their contrasting response to $\mathrm{Al}^{3+}$ stress observed in our previous studies (Silva et al. 2019).

\section{RESULTS AND DISCUSSION}

Relative expression data revealed differences between miR160, miR395, and miR6225-5p expression levels in sugarcane roots under $\mathrm{Al}^{3+}$ stress (Figure 1). Of these, miR6225-5p exhibited a contrasting response in the tolerant and sensitive genotypes and miR160 was suppressed in both genotypes; however, miR395 was not responsive in the sensitive genotype but was expressed in the tolerant genotype. Previous studies have been reported to show such a differential expression of miRNAs, including miR395 and miR167, in response to different abiotic stresses (Zhang et al. 2013, Li et al. 2017). Gao et al. (2019) demonstrated the differential expression of miRNAs, including miR159, miR160, miR166, and miR319 in corn plants exposed to heavy metals such as Al and cadmium (Cd).

The predicted target genes regulated by the evaluated miRNAs are shown in Table 2. The results indicated that ATPsulfurylase (APS4) and sulfate transporter 2.1 (SULTR2;1) genes were regulated by miR395, whereas the auxin response factor 17 (ARF17) transcription factor was regulated by miR160. No report was available on the target genes of miR6225-
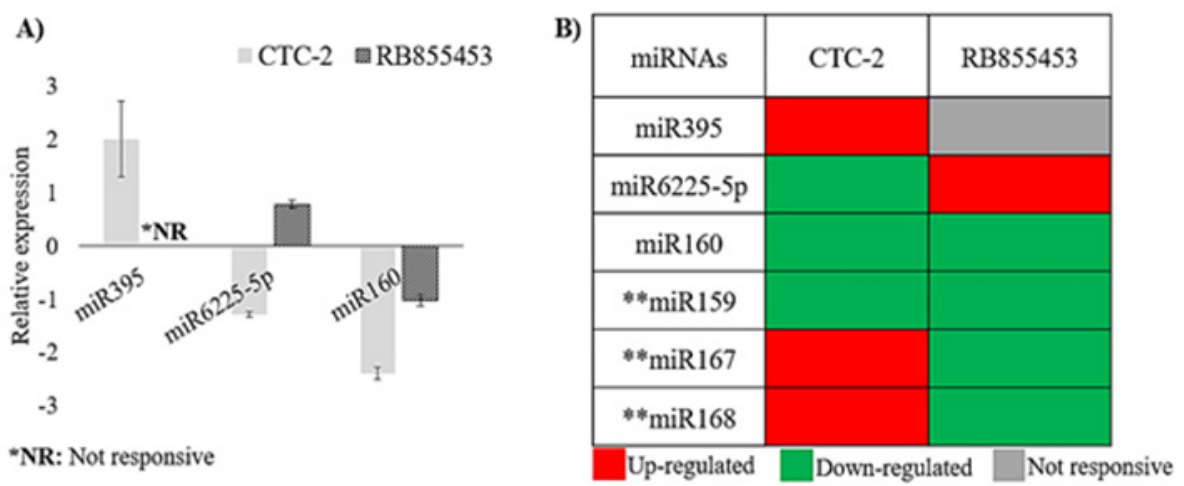

Figure 1. Relative expression of identified miRNAs in sugarcane roots under $\mathrm{Al}^{3+}$ stress. A) miRNAs validated by RT-qPCR in the present study; B) miRNAs analyzed by research groups (** other studies). 
$5 p$. However, this study identified two possible target genes for miR6225-5p: the kinesin-like protein KIN-12E (KIN12E) gene, which is involved in microtubule movement and cytokinesis, and the SIT4 phosphatase-associated family protein (SIT4) gene, a protein phosphatase regulator (Tables 2 and 3).

The evaluated miRNAs can regulate several target genes and are thus involved in various biological processes. Based on target prediction (Tables 2 and 3), the 1-aminocyclopropane-1-carboxylate synthase 8 (ACS8), ARF17, F-box protein 5 (FBX5), allantoate deiminase (AAH), SULTR2;1, and KIN12E genes were selected for further analysis of some biological processes. This study analyzed a co-expression network, which includes miR168 and miR395 targets, and the multidrug and toxic compound extrusion transporter (MATE) gene, which encodes a transmembrane citrate transporter (Ma et al. 2018) (Figure 2). The SULTR2;1 gene encodes a transmembrane sulfate transporter (Table 3) that is co-expressed directly with MATE and other sulfate transporter genes (SULTRs). Of the SULTRs genes identified in the network, SULTR3;1 and SULTR3;3 were co-expressed with MATE and AAH genes included in neighboring networks, respectively (Figure 2).

Table 2. Summary of predicted miRNA targets

\begin{tabular}{|c|c|c|c|c|}
\hline miRNA & Sequence $^{1}$ & PsRNA Target & WMD3 $^{2}$ & Inhibition $^{3}$ \\
\hline \multirow{2}{*}{ miR159 } & \multirow{2}{*}{ UUUGGAUUGAAGGGAGCUCUG } & ACS8 & MYB104 & \multirow{2}{*}{ Cleavage } \\
\hline & & MYB101 & & \\
\hline miR160 & UGCCUGGCUCCCUGUAUGCCG & ARF17 & $A R F 17$ & Cleavage \\
\hline \multirow{2}{*}{ miR167 } & \multirow{2}{*}{ AGGUCAUGCUGUAGUUUCAUC } & FBX5 & \multirow{2}{*}{$\mathrm{Nr}$} & \multirow{2}{*}{ Cleavage } \\
\hline & & ATHB6 & & \\
\hline \multirow{2}{*}{$\operatorname{miR} 168$} & \multirow{2}{*}{ UCGCUUGGUGCAGAUCGGGAC } & $A A H$ & \multirow{2}{*}{$\mathrm{Nr}$} & \multirow{2}{*}{ Cleavage } \\
\hline & & AGO1 & & \\
\hline \multirow{2}{*}{ miR395 } & \multirow{2}{*}{ CUGAAGUGUUUGGGGGAACUCC } & SULTR2;1 & \multirow{2}{*}{ SULTR2;1 } & \multirow{2}{*}{ Cleavage } \\
\hline & & APS4 & & \\
\hline \multirow{2}{*}{$\operatorname{miR} 6225-5 p$} & \multirow{2}{*}{ AACUAGACUCAAAAGAUUCAUCUC } & KIN12E & \multirow{2}{*}{$\mathrm{Nr}$} & \multirow{2}{*}{ Translation } \\
\hline & & SIT4 & & \\
\hline
\end{tabular}

${ }^{1}$ Sequence from miRBASE (http://www.mirbase.org/); ${ }^{2} \mathrm{Nr}$ : not results. ${ }^{3}$ Type of regulation carried out by miRNA.

Table 3. Functional annotation of targets regulated by miRNAs

\begin{tabular}{|c|c|c|c|c|c|}
\hline MiRNA & Target & Acess number & Molecular function & Biological process & Subcellular localization \\
\hline $\operatorname{miR} 159$ & ACS8 & AT4G37770.1 & $\begin{array}{l}\text { 1-aminocyclopropane-1-carboxy- } \\
\text { late synthase activity and protein } \\
\text { binding }\end{array}$ & $\begin{array}{l}\text { Ethylene biosynthetic process and } \\
\text { 1-aminocyclopropane-1-carboxylate } \\
\text { biosynthetic process }\end{array}$ & Cytoplasm \\
\hline $\operatorname{miR} 160$ & ARF17 & AT1G77850.1 & $\begin{array}{l}\text { DNA-binding transcription fator } \\
\text { activity }\end{array}$ & $\begin{array}{l}\text { Adventitious root development and } \\
\text { auxin-activated signalling pathway }\end{array}$ & Nucleus \\
\hline $\operatorname{miR} 167$ & ATHB6 & AT2G22430.1 & DNA-binding and protein binding & $\begin{array}{l}\text { Abscisic acid-activated signalling } \\
\text { pathway }\end{array}$ & Nucleus \\
\hline \multirow{2}{*}{$\operatorname{miR} 168$} & $A A H$ & AT4G20070.1 & $\begin{array}{l}\text { Allantoate deiminase activity and } \\
\text { metalopeptidase activity }\end{array}$ & Proteolysis and ureide catabolic process & $\begin{array}{l}\text { Chloroplast and endo- } \\
\text { plasmic reticulum }\end{array}$ \\
\hline & AGO1 & AT1G48410.3 & $\begin{array}{l}\text { Endoribonuclease activity, mRNA } \\
\text { binding and protein binding }\end{array}$ & $\begin{array}{l}\text { Auxin metabolic process, cell differentia- } \\
\text { tion, and gene silencing by mRNA }\end{array}$ & $\begin{array}{l}\text { Cytoplasm, cytosol, } \\
\text { and nucleus }\end{array}$ \\
\hline \multirow{2}{*}{ miR395 } & SULTR2;1 & AT5G10180.1 & $\begin{array}{l}\text { Sulfate transmembrane transporter } \\
\text { activity }\end{array}$ & Sulfate transport & $\begin{array}{l}\text { Integral component of } \\
\text { plasma membrane }\end{array}$ \\
\hline & APS4 & AT5G43780.1 & $\begin{array}{l}\text { Sulfate adenylyltransferase (ATP) } \\
\text { activity }\end{array}$ & Sulfate assimilation & $\begin{array}{l}\text { Chloroplast, plastid, } \\
\text { and mitochondrion }\end{array}$ \\
\hline \multirow{2}{*}{$\begin{array}{l}\operatorname{miR} 6225- \\
5 p\end{array}$} & KIN12E & AT3G44050.1 & $\begin{array}{l}\text { ATPase activity and microtubule } \\
\text { binding }\end{array}$ & $\begin{array}{l}\text { Microtubule-based movement and } \\
\text { cytokinesis }\end{array}$ & $\begin{array}{l}\text { Cytoplasm, kinesin } \\
\text { complex, and micro- } \\
\text { tubule }\end{array}$ \\
\hline & SIT4 & AT1G07990.1 & $\begin{array}{l}\text { Protein phosphatase regulator } \\
\text { activity }\end{array}$ & Regulation of phosphoprotein activity & $\begin{array}{l}\text { Cytoplasm and chlo- } \\
\text { roplast }\end{array}$ \\
\hline
\end{tabular}


The ACS8, ARF17, and FBX5 target genes integrated the co-expression network shown in Figure 3. ARF17 is the co-expression of ACS8 and FBX5 through long chain base (LCB) and protein TOPLESS (TPL) targets. The AAH gene, related to ureide and allantoin metabolism, protects plants by controlling oxidative damage (Nourimand and Todd 2016). The probable positive regulation of the AAH gene in the RB855453 genotype (repressed miR168) may indicate a potential antioxidant defense pathway for reducing oxidative damage in this genotype under $\mathrm{Al}^{3+}$ stress. Arabidopsis sp. exhibits higher allantoin under $\mathrm{Cd}$ toxicity, suggesting higher activities of antioxidant enzymes, such as superoxide dismutase (SOD) and ascorbate peroxidase (APX) (Nourimand and Todd 2016). Repression of AAH cannot explain this mechanism in the CTC-2 genotype (induced miR168); however, other antioxidant defense pathways can be activated by differential expression of other miRNAs under $\mathrm{Al}^{3+}$ stress, such as miR398 repression and possible copper/zinc SOD induction (Silva et al. 2019).

The ACS8 gene is involved in the ethylene biosynthetic pathway (Table 3 ). The development of lateral and primary roots is mediated by phytohormone signaling pathways, such as ethylene and auxin, which coordinate root growth during development (internal factor) and in response to environmental conditions (external factor) (Waidmann et al. 2020). Repression of miR159 in both sugarcane genotypes (CTC-2 and RB855453) indicates the probable induction of the ACS8 gene and the consequent modulation of root growth under $\mathrm{Al}^{3+}$ stress. This response triggered in the root system was also explained based on the relationship between miR159 and the predicted MYB target (Silva et al. 2019)

These co-expressions between targets and differential expression of the miRNAs evaluated in the present and previous

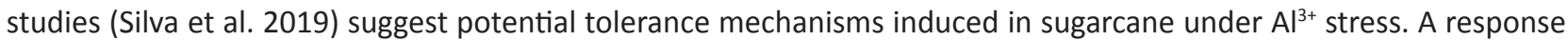
model summarized two mechanisms related to tolerance of the CTC-2 genotype (Figure 4), that is, a detoxification mediated by miR395 and a development of lateral roots mediated by miR160, miR6225-5p, and miR167. The presented model is highly hypothetical; therefore, we understand the importance of searching for biological evidence on the role of these miRNAs in sugarcane tolerance under Al stress.

Some members of the MATE family are involved in Al detoxification in plants and are responsible for releasing citrate (an Al chelator) from the roots into the rhizosphere in response to Al stress (Ma et al. 2018). The secretion of organic Al-chelating acids (malate and citrate) by MATE transporters facilitates the elimination of $\mathrm{Al}^{3+}$ and $\mathrm{Cu}^{2+}$, thus improving root $P$ and Fe availability (Wang et al. 2017). Furthermore, nutrient deprivation, such as that of $S$, is common under $A^{l^{3+}}$ stress (Alarcón-Poblete et al. 2018). The SULTR2;1 gene is functional mainly during conditions of sulfate deprivation (Jagadeeswaran et al. 2014). The co-expression between SULTR2;1 and MATE suggests the participation of the former in the Al detoxification process, controlling the flow of sulfate under $\mathrm{S}$ deprivation.

Induction of miR395 probably negatively regulates the SULTR2;1 gene, controlling the flow of sulfate from roots to aerial plant parts (Capaldi et al. 2015) and consequently promoting the formation of the $\mathrm{AlSO}_{4}{ }^{+}$complex and detoxification of Al (Vera-Villalobos et al. 2020) in the CTC-2 genotype (Figure 4). miR395 induction during sulfate deprivation and consequent SULTR2;1 repression has previously been established. Oxidative stress caused by sulfate deprivation and excess $\mathrm{Cu}^{2+}$ ions in Arabidopsis plants indicate that redox signaling induces miR395 (Jagadeeswaran et al. 2014). 
In addition, miR6225-5p and miR160 were suppressed in CTC-2 plants, possibly inducing KIN12E and ARF17 target genes involved in cell expansion process (Vanstraelen et al. 2006) and auxin-mediated signaling, respectively (Table 3). Conversely, miR167 was induced, possibly suppressing FBX5. The co-expression between these miRNAs explains the adaptation mechanism of the root system under $\mathrm{Al}^{3+}$ stress (Figure 4).

Under stress conditions, the root system adapts to improve water and nutrient uptake. $\mathrm{Al}^{3+}$ stress negatively affects roots by altering cell division; however, plants tolerant to $\mathrm{Al}^{3+}$ can maintain root growth under stress conditions (Adawiyah 2019). Cell wall changes and root elongation were observed in tea plants (Camellia sinensis) under $\mathrm{Al}^{3+}$ stress, indicating the participation of proteins involved in root cell expansion (Safari et al. 2018). The KIN12E gene belongs to the family of microtubule motor proteins, functioning mainly at the cellular level in the organization of microtubules and cell division (Nebenführ and Ditix 2018). Thus, this gene, which is possibly induced in the CTC-2 genotype, improves cell expansion, subsequently promoting lateral root formation.

Auxins control the cell division process for the development of lateral roots (Khan et al. 2016). In this context, auxin response factors (ARFs) regulate auxin hormone perception (Yamauchi et al. 2019) and play a crucial role in lateral root formation. miR160 was repressed in rice plants under chromium stress, consequently inducing auxins in response to stress (Dubey et al. 2020).

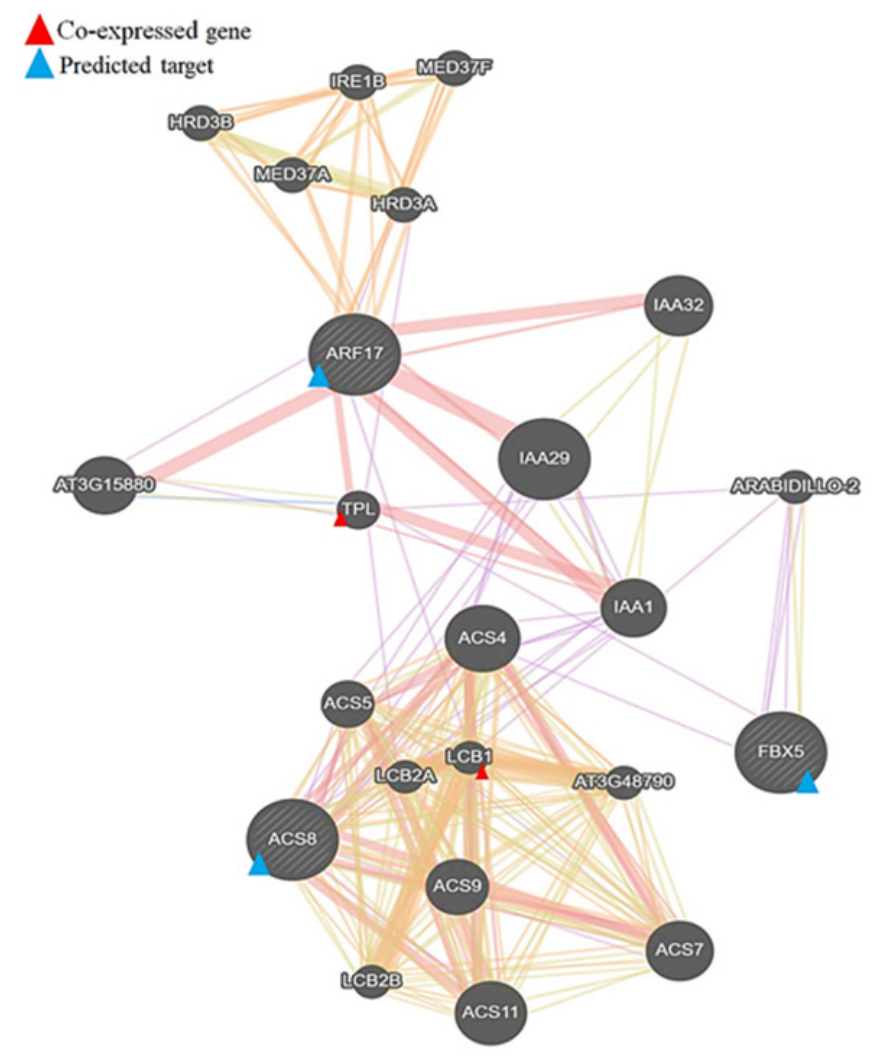

Figure 3. Co-expression network for the ARF17, ACS8, and FBX5 targets. Each circle represents a gene, and the type of interaction between them is determined from the lines. Co-expression between genes (positive or negative correlation) is observed on the purple line.

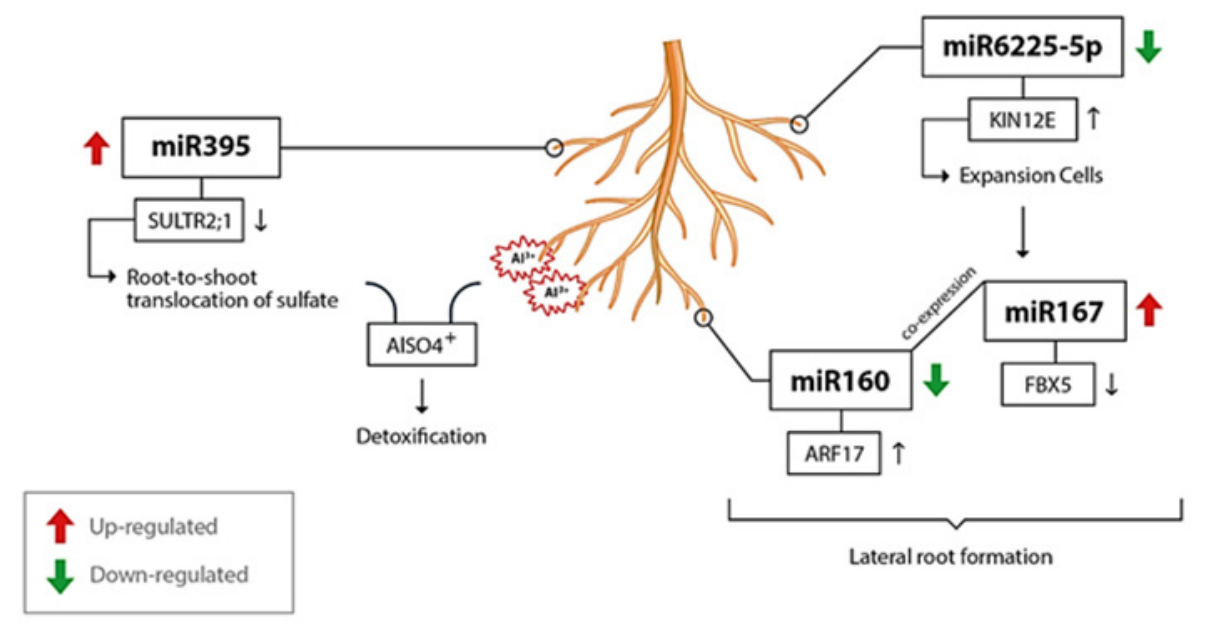

Figure 4. A hypothetic model for $\mathrm{Al}^{3+}$ stress responses in CTC-2 root. $\mathrm{Al}^{3+}$ induces the differential expression of miR395, miR6225$5 p$, miR167, and miR160, and possible modulation of their respective targets indicates that detoxification and root development mechanisms are influenced in the sugarcane tolerance. 
ARABIDILLO function and degradation are not affected by hormonal signals. Plants lacking or overexpressing ARABIDILLO 1 respond normally to regulatory signals, such as auxins and abscisic acid (ABA) (Nibau et al. 2011). That is, FBX5 (ARABIDILLO 1) functions independently of the auxins, suggesting that the possible negative regulation of this gene does not affect root development; however, the ARF17 transcription factor modulates lateral root production in the CTC-2 genotype via co-expression of ARF17 with FBX5, enhancing plant adaptation to stress (Rao et al. 2016) (Figure 4). These results might be useful for genetic improvement programs aimed at developing novel and more productive sugarcane genotypes that are tolerant to high environmental concentrations of Al.

\section{ACKNOWLEDGMENTS}

Thanks to Coordenação de Aperfeiçoamento de Pessoal de Nível Superior (CAPES) for the scholarship granted (Finance Code 001). Fundação de Amparo a Pesquisa do Estado de São Paulo (FAPESP) for financial support.

\section{REFERENCES}

Adawiyah R (2019) Mechanism of toxicity and tolerance in plants against aluminum stress. Agrotech Journal 4: 16-22.

Alarcón-Poblete E, Inostroza-Blancheteau C, Alberdi M, Rengel Z and Reyes-Díaz M (2018) Molecular regulation of aluminum resistance and sulfur nutrition during root growth. Planta 247: 27-39.

Capaldi FR, Gratão PL, Reis AR, Lima LW and Azevedo RA (2015) Sulfur metabolism and stress defense responses in plants. Tropical Plant Biology 8: 60-73.

Çelik O and Akdas EY (2019) Tissue-specific transcriptional regulation of seven heavy metal stressresponsive miRNAs and their putative targets in nickel indicator castor bean ( $R$. communis $L$.) plants. Ecotoxicology and Environmental Safety 170: 682-690.

Dai X, Zhuang Z and Zhao PX (2018) psRNATarget: a plant small RNA target analysis server (2017 release). Nucleic Acids Research 46: 49-54.

Devarumath RM, Mirajkar SJ, Thorat AS, Farsangi FJ and Suprasanna $P$ (2019) Genomic landscapes of abiotic stress responses in sugarcane. In Rajpal V, Sehgal D, Kumar A, Raina S (eds) Genomics assisted breeding of crops for abiotic stress tolerance. sustainable development and biodiversity. Springer, Cham, p. 225-240.

Dubey S, Saxena S, Chauhan AS, Mathur P, Rani V and Chakrabaroty D (2020) Identification and expression analysis of conserved microRNAs during short and prolonged chromium stress in rice (Oryza sativa). Environmental Science and Pollution Research 27: 380-390.

FAOSTAT- Food and Agriculture Organization of the United Nations (2018) Available at: <http://www.fao.org/faostat/en/\#data/QC/visualize>. Accessed on June 29, 2020.

Gao J, Luo M, Peng H, Chen F and Li W (2019) Characterization of cadmium-responsive MicroRNAs and their target genes in maize (Zea mays) roots. BMC Molecular Biology 20: 1-9.

Inostroza-Blancheteau C, Reyes-Díaz M, Aquea F, Nunes-Nesi A, Alberdi $M$ and Arce-Johnson P (2011) Biochemical and molecular changes in response to aluminium-stress in highbush blueberry (Vaccinium corymbosum L.). Plant Physiology and Biochemistry 49: 1005-1012.

Jagadeeswaran G, Li Y-F and Sunkar R (2014) Redox signaling mediates the expression of a sulfate-deprivation-inducible microRNA395 in
Arabidopsis. The Plant Journal 77: 85-96.

Khan MA, Gemenet DC and Villordon A (2016) Root system architecture and abiotic stress tolerance: current knowledge in root and tuber crops. Frontiers in Plant Science 7: 1-13.

Kong X, Zhang M, Xu X, Li X, Li C and Ding Z (2014) System analysis of microRNAs in the development and aluminium stress responses of the maize root system. Plant Biotechnology Journal 12: 1108-1121.

Li L, Yi H, Xue M and Yi M (2017) miR398 and miR395 are involved in response to SO2 stress in Arabidopsis thaliana. Ecotoxicology 26: 1181-1187.

Liu J, Piñeros MA and Kochian LV (2014) The role of aluminum sensing and signaling in plant aluminum resistance. Journal of Integrative Plant Biology 56: 221-230.

Ma Q, Yi R, Li L, Liang Z, Zeng T, Zhang $Y$, Huang $H$, Zhang $X$, Yin $X$, Cai Z, Mu Y, Chen Y, Zeng Q, Li X and Nian H (2018) GsMATE encoding a multidrug and toxic compound extrusion transporter enhances aluminum tolerance in Arabidopsis thaliana. BMC Plant Biology 18: $1-10$.

Nebenführ A and Dixit R (2018) Kinesins and myosins: molecular motors that coordinate cellular functions in plants. Annual Review of Plant Biology 69: 329-361.

Nibau C, Gibbs DJ, Bunting KA, Moody LA, Smiles EJ, Tubby JÁ, Bradshaw SJ and Coates JC (2011) Arabidillo proteins have a novel and conserved domain structure important for the regulation of their stability. Plant Molecular Biology 75: 77-92.

Nogueirol RC, Monteiro FA, Gratão PL, Borgo L and Azevedo RA (2015) Tropical soils with high aluminum concentrations cause oxidative stress in two tomato genotypes. Environmental Monitoring Assessment 187: 1-16.

Nourimand M and Todd CD (2016) Allantoin increases cadmium tolerance in Arabidopsis via activation of antioxidant mechanisms. Plant \& Cell Physiology 57: 2485-2496.

Pandey P, Srivastara S, Pandey AK and Dubey RS (2020) Abiotic-stress tolerance in plants-system biology approach. In Tripathi DK, Singh VP, Chauhan DK, Sharma S, Prasad SM, Dubey NK and Ramawat $N$ (eds) Plant life under changing environment. Academic Press, 


\section{JOL Silva et al.}

Amsterdam, p. 577-609.

Rao IM, Miles JW, Beebe SE and Horst WJ (2016) Root adaptations to soils with low fertility and aluminium toxicity. Annals of Botany 118: 593-606.

Rao X and Dixon RA (2019) Co-expression networks for plant biology: why and how. Acta Biochimica et Biophysica Sinica 81: 981-988.

Safari M, Ghanati F, Safarnejad MR and Chashmi NA (2018) The contribution of cell wall composition in the expansion of Camellia sinensis seedlings roots in response to aluminum. Planta 247: 381392.

Schwab R, Ossowski S, Riester M, Warthmann N and Weigel D (2006) Highly specific gene silencing by artificial microRNAs in Arabidopsis. Plant Cell 18: 1121-1133.

Silva RG, Rosa-Santos TM, França SC, Kottapalli P, Kottapalli KR and Zingaretti SM (2019) Microtranscriptome analysis of sugarcane cultivars in response to aluminum stress. Plos One 14: 1-12.

Torquato SA and Ramos RC (2013) Biomassa da cana-de-açúcar e a geração de bioeletricidade em São Paulo: usinas signatárias ao protocolo agroambiental paulista. Informações Econômicas 43: 59-68.

Vanstraelen M, Inze D and Geelen D (2006) Mitosis-specific kinesins in Arabidopsis. Trends in Plant Science 11: 167-175.

Varkonyi-Gasic E and Hellens RP (2011) Quantitative stem-loop RT-PCR for detection of microRNAs. In Kodama $\mathrm{H}$ and Komamine $\mathrm{A}$ (eds) RNAi and plant gene function analysis. Springer, New York, p. 145-157.

Vera-Villalobos H, Lunario-Delgado L, Pérez-Retamal D, Román D, Leiva JC, Zamorano P, Mercado-Seguel A, Gálvez AS, Benito C and Wulf-Zottele $C$ (2020) Sulfate nutrition improves short-term $A \mid 3^{3+}$-stress tolerance in roots of Lolium perenne L. Plant Physiology and Biochemistry 148: 103-113.

Waidmann S, Sarkel E and Kleine-Vehn J (2020) Same same, but different: growth responses of primary and lateral roots. Journal of
Experimental Botany 71: 2397-2411.

Walley JW, Sartor RC, Shen Z, Schmitz RJ, Wu KJ, Urich, MA, Nery JR, Smith LG, Schnable JC, Ecker JR and Briggs SP (2016) Integration of omic networks in a developmental atlas of maize. Science 353: 814-818.

Wang J, Hou Q, Li P, Yang L, Sun X, Benedito VA, Wen J, Chen B, Mysore KS and Zhao J (2017) Diverse functions of multidrug and toxin extrusion (MATE) transporters in citric acid efflux and metal homeostasis in Medicago truncatula. The Plant Journal 90: 79-95.

Ward-Farley D, Donaldson SL, Comes O, Zuberi K, Badrawi R, Chao $P$, Franz M, Grouios C, Kazi F, Lopes CT, Maitland A, Mostafavi S, Montojo J, Shao Q, Wright G, Bader GD and Morris Q (2010) The GeneMANIA prediction server: biological network integration for gene prioritization and predicting gene function. Nucleic Acid Research 38: 214-220.

Wu L, Yu J, Shen Q, Huang L, Wu D and Zhang G (2018) Identification of microRNAs in response to aluminum stress in the roots of Tibetan wild barley and cultivated barley. BMC Genomics 19: 1-14.

Xie M, Zhang S and Yu B (2015) microRNA biogenesis, degradation and activity in plants. Cellular and Molecular Life Sciences 72: 87-99.

Yamauchi T, Tanakaa A, Inahashia H, Nishizawac NK, Tsutsumic N, Inukaib $Y$ and Nakazono M (2019) Fine control of aerenchyma and lateral root development through AUX/IAA- and ARF-dependent auxin signaling. Proceedings of the National Academy of Sciences of the United States of America 116: 1-6.

Zeng QY, Yang CY, Ma QB, Li XP, Dong WW and Nian H (2012) Identification of wild soybean miRNAs and their target genes responsive to aluminum stress. BMC Plant Biology 12: 182.

Zhang Q, Zhao C, Li M, Sun W, Liu Y, Xia H, Sun M, Li A, Li C, Zhao S, Hou L, Picimbon J, Wang X and Zhao Y (2013) Genome-wide identification of Thellungiella salsuginea microRNAs with putative roles in the salt stress response. BMC plant biology 13: 1-13. 